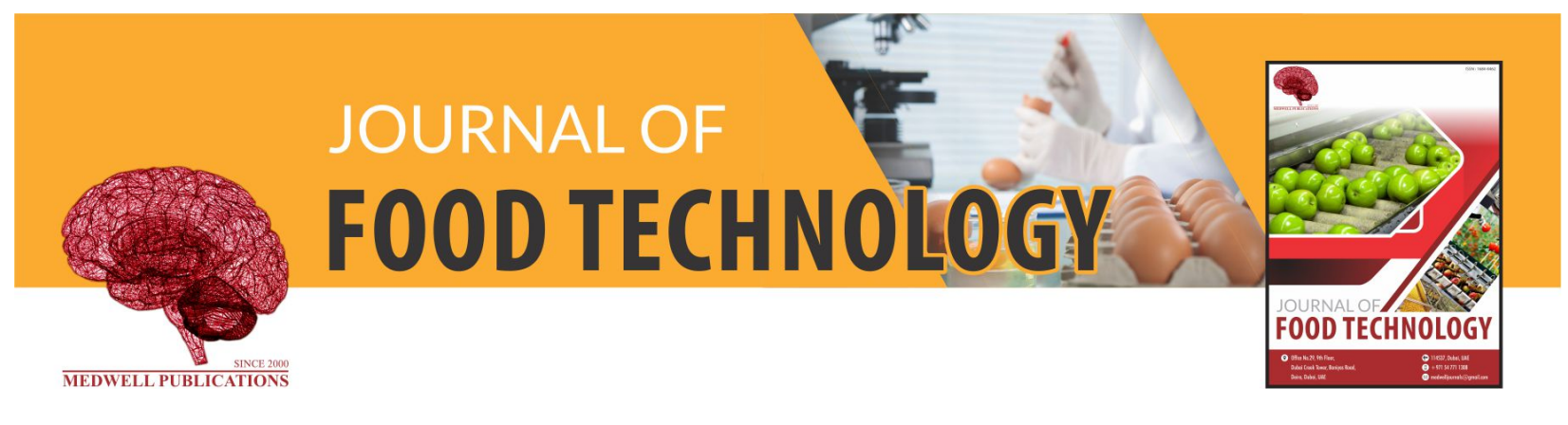

\title{
Sterilization of Bovine Milk Using Different Laser Wavelengths
}

\author{
Walaa Sabri, Adnan W. Al Mudhfar and Ayad J. Al-Khafaji \\ Department of Food Science, Agriculture College, Kufa University, Kufa, Iraq
}

Key words: Light wave, laser diode, milk, microbial, inactivation

Corresponding Author:

Walaa Sabri

Department of Food Science, Agriculture College, Kufa University, Kufa, Iraq

Page No.: 5-8

Volume: 18, Issue 1, 2020

ISSN: $1684-8462$

Journal of Food Technology

Copy Right: Medwell Publications
Abstract: In this study, we study the effect of different laser wavelengths in raw milk sterilization. The milk treatment sample with LD laser $(650,810$ and $1064 \mathrm{~nm})$ was investigated. The microbial inactivation of different microorganism was achieved with laser source power $70 \mathrm{~mW}$ at hold time $1.5 \mathrm{~min}$ for all laser wavelengths, the study showed that the maximum microbial reduction $(100 \%)$ was obtained at $650 \mathrm{~nm}$ for the same operating conditions. There was no significant variation in physical chemical properties of treatment sample in comparing with control milk sample.

\section{INTRODUCTION}

Human has known milk, since, ancient as a natural food integrated because of the contain most of the basic nutrients and search for several ways to prolong the storage time but there are some problems stand in the way of interested such as the flavor of oxidation and taste semi-cartons or lipids which develops over time because of the storage is not good and therefore, composition of volatile compounds resulting from oxidation of fat or taste cooked due to high temperature ${ }^{[1]}$. In addition, many types of microorganisms can be observed in milk that affects its quality as well as its negative impact on the health and safety of the consumer. Therefore, many researchers have sought to develop methods of pasteurization ${ }^{[2]}$ because of the side effects caused by thermal sterilization, researchers resorted to the use of non-heat sterilization in the preservation of raw milk and its products and the most important methods of cold sterilization its light (laser) sterilization $^{[3]}$.

The laser in the infrared region near and mid infrared is strongly absorbed by the water inside the bacterial cell, causing a gradual rise in the temperature inside the bacterial cell causing the deposition of DNA inside the cell and the plasmodium plutonic proteins that damage the cell bone and enzymes. While the laser in the visible and ultraviolet region has the potential to cause chemical reactions in living molecules based on the absorption of light which depends on the type of living cell and its nuclear composition. The cause of the loss, here is a genetic change in the cells exposed to radiation.

The proposed work based on design and implementation sterilized laser system at three different wavelengths $(810,1046,650) \mathrm{nm}$ that located within IR and visible region in $\mathrm{CW}$ mode, $70 \mathrm{~mW}$ at hold time $1.5 \mathrm{~min}$. The comparison between different wavelengths was achieved to prove the $100 \%$ inactivation ratio, for the total number of bacteria, intestinal bacteria, yeasts and labs and also study the effect of the treatments on milk content of amino acids ${ }^{[4]}$.

\section{MATERIALS AND METHODS}

In our experiments, we use the following materials as shown in Table 1.

Devices and tools: The proposed device was implemented using the following apparatus listed in Table 2. 
Table 1: The experiments

\begin{tabular}{lll}
\hline Manufacture company & Scientific term & Materials \\
\hline Himedia, India & Nutrient Agar & Medium solid nitrites \\
Himedia, India & Maconkey Agar & E. coli medium \\
Himedia, India & Salmonella & Salmonella \\
& shigella Agar & medium \\
Himedia, India & Raw milk & Raw milk \\
Himedia, India & Alt extract M & Fungi and yeast medium \\
\hline
\end{tabular}

Table 2: Device name

\begin{tabular}{ll}
\hline Device name & Origin \\
\hline Laser diode & America \\
Sensitive balance & Germany \\
Incubator & China \\
Autoclave & China \\
\hline
\end{tabular}

\section{Working methods}

Microbiological tests: All microbiological tests on milk samples were performed before and after sterilization process. We take $(11 \mathrm{~mL})$ samples from sterilized and raw milk all samples added $99 \mathrm{~mL}$ of peptone water with well mix and we take $1 \mathrm{~mL}$ from each sample to perform dilution, number of it six dilution. The fifth dilution was used for agriculture. Sterile test tubes and tubes were used for this purpose, according to Krishnamurthy et al. ${ }^{[5]}$.

Determination of the total bacterial account: In this section, we use nutrient Agar from India's Himedia company ${ }^{[6]}, 28 \mathrm{~g}$ which was dissolved in one liter of distilled water and sterilized at $121^{\circ} \mathrm{C}$ for $15 \mathrm{~min}$ agro-medium to calculate the total number of bacteria and then incubated at $37^{\circ} \mathrm{C}$ for $24-48 \mathrm{~h}$. Then, the developing bacterial setting is calculated.

Determination of colon bacteria: Equip the Macon key agar from India's Himedia company and attend to dissolve $51.5 \mathrm{~g}$ of it in one liter of distilled water and then sterilize with a $121^{\circ} \mathrm{C}$ cascade for $15 \mathrm{~min}$ min. Then, incubate at $37^{\circ} \mathrm{C}$ for $48-24 \mathrm{~h}$. The developing colonies are then counted.

Determination of yeasts and modules: The medium Malt Extract Agar extract malt was prepared from India's Himedia Company and was attended to by dissolving 39 of it in one liter of distilled water and then sterilized with a $212^{\circ} \mathrm{C}$ for $15 \mathrm{~min}$. Then incubate at $28-25^{\circ} \mathrm{C}$ for $72-48 \mathrm{~h}$. Then, the developing setting is calculated.

\section{RESULTS AND DISCUSSION}

Effect of laser sterilization on microbial load of milk.

Total account of bacteria A. Laser $650 \mathrm{~nm}$ : Figure 1 represents the results of the sterilization process using the laser system with a wavelength of $650 \mathrm{~nm}$ at a power $70 \mathrm{~mW}$ and a hold time $1.5 \mathrm{~min}$ where can note the reduction ratio reach to $100 \%$. The total number of

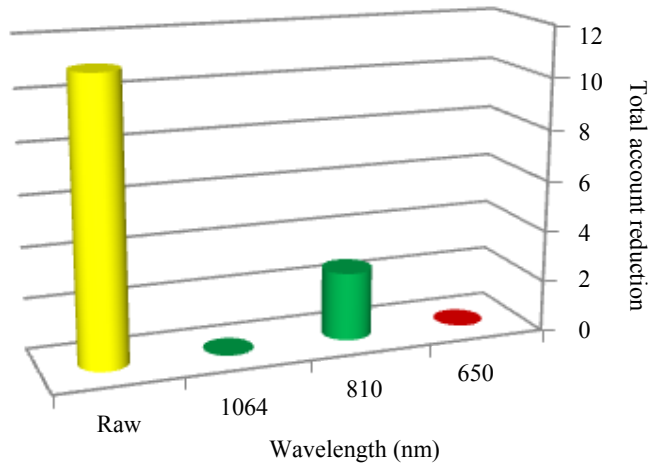

Fig. 1: The effect of different laser wavelengths on total number of bacterial

bacteria dropped to zero. The reason for this reduction is that the $650 \mathrm{~nm}$ laser is located within the visible region and is slightly absorbed by milk in this area. For microorganisms in general, their DNA or RNA absorbs light within this range because they have the ring structure of nucleic acids in the nitrogen bases, so, the killing mechanism depends on the formation of compounds in the nucleic acids of the bacterial cell (Cyclo butyl byrimidin, dimer, byrimidine byrimidinone Dewar byrimidinone Adeninethymines heterodimer). And working to build the links between spin cell DNA and cytoplasmic proteins (DNA protein cross link). The formation of these compounds loses the cell's ability to divide and feed. Which showed that DNA microorganisms in general absorb the light strongly in the visible region and there are chemical reactions that disrupt the cell metabolism and cause its destruction.

Laser 810 nm: In Fig. 1, when using a $810 \mathrm{~nm}$ wavelength of $70 \mathrm{~mW}$ with a 1.5 min hold time in milk sterilization, this wavelength significantly reduced the total number of bacteria to $4.667 \times 10^{5} \mathrm{CFU} \mathrm{mL}^{-1}$. This is because the $810 \mathrm{~nm}$ laser is located within the nearby infrared region. The photon energy in this region causes vibration of the electrons to turn into heat. Since, the bacterial cell contains $70 \%$ water, it causes heat inside the cell when it absorbs light. DNA breakdown in cytoplasm, dysfunction of plasma membrane and damage to cellular metabolism by enzymatic breakdown, causing bacterial cell death which achieved a reduction of $5 \times 10^{5}$ and ET with a dose of $2 \mathrm{~J} / \mathrm{cm} 3$ for a time of $5 \mathrm{~min}$.

Laser 1064 nm: A $1064 \mathrm{~nm}$ wavelength laser was used with the same laser power and hold time. Figure 1 showed that the total number of bacteria decreased

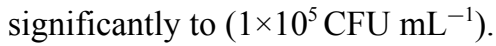

This is because the $1064 \mathrm{~nm}$ wavelength is located within the medium infrared region. It is a continuous pattern that is absorbed by the fluid inside the cell and 


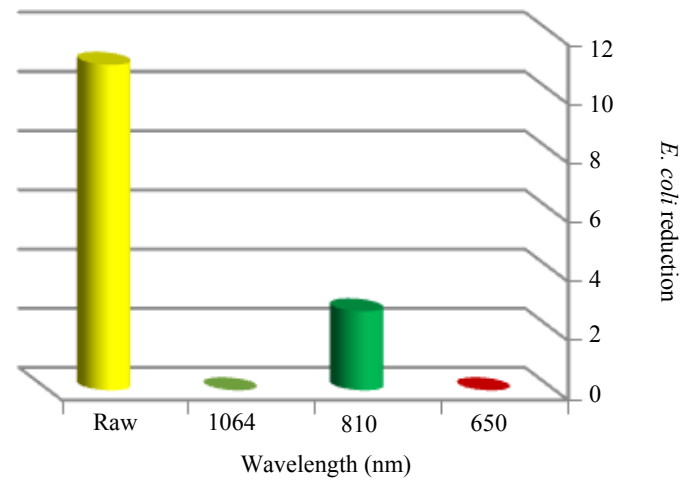

Fig. 2: The effect of different laser wavelengths on $E$. coli

causes a gradual increase in cell temperature. This causes the deposition of cell proteins and the breakdown of DNA as well as the mechanical effect of rupturing the cell wall. We can note from our results of proposed work the laser beam with a $650 \mathrm{~nm}$ wavelength within the visible area significantly exceeded all the treatments by reducing the total number of bacteria to zero. Therefore, its use was not used for this research and for the manufacture of the system.

\section{$E$. coli bacteria}

Laser $650 \mathrm{~nm}$ : Figure 2 shows the total number of intestinal bacteria decreased to zero and $\mathrm{CFU} \mathrm{mL} \mathrm{m}^{-1}$ after exposure to $650 \mathrm{~nm}$ laser with a powery of $70 \mathrm{~mW}$ and a $1.5 \mathrm{~min}$ hold time. The reason for the decrease is the photon energy in this region it is high and the absorption coefficient of the milk is very low in the visible area led to the full absorption of energy by the DNA of the bacterial cell which led to its destruction.

Laser $810 \mathrm{~nm}$ : Figure 2 shows the effect of the laser at a wavelength of $810 \mathrm{~nm}$ and a capacity of $70 \mathrm{~mW}$ and a $1.5 \mathrm{~min}$ survival time on the intestinal bacteria. The number of intestinal bacteria decreased to $3 \times 10^{5} \mathrm{CFU} \mathrm{mL} \mathrm{mL}^{-1}$. Compared to the sample of raw milk which was the number of colonies $\left(9 \times 10^{5}\right) \mathrm{CFU} \mathrm{mL-}{ }^{1}$ due to low energy and shorten the time of stay as the loss increases with increasing capacity and time of exposure.

Laser 1064 nm: It is noted from Fig. 2 that the total number of intestinal bacteria decreased to $\left(0.333 \times 10^{5}\right) \mathrm{CFU} \mathrm{mL} \mathrm{m}^{-1}$. The increase in the loss is due to the increase of bacterial cell absorption of light at the wavelength $1064 \mathrm{~nm}$ and low absorption of milk, high heat inside the bacterial cell compared to the ocean breaks up the DNA and breaks down the plasmid membrane. Increase microorganism loss by low absorption factor sterile material.

\section{Salmonella account}

Laser $650 \mathrm{~nm}$ : The results of the statistical analysis shown in Fig. 3 of the laser sample with a wavelength of

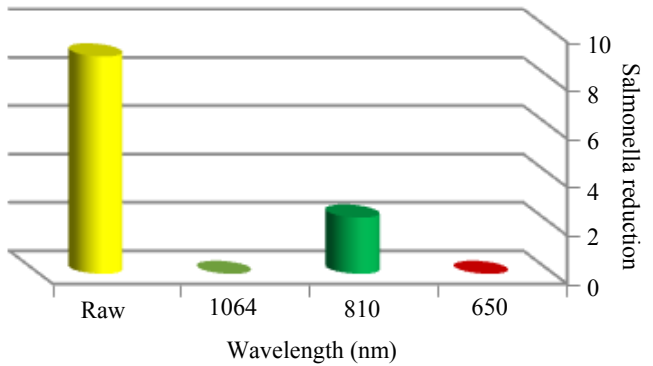

Fig. 3: The effect of different laser wavelengths on Salmonella

$650 \mathrm{~nm}$ at a capacity of $70 \mathrm{~mW}$ and a survival time of $1.5 \mathrm{~min}$ showed a significant decrease of 0.01 for the number of Salmonella bacteria from $9 \times 10^{5} \mathrm{CFU}$.

Laser $810 \mathrm{~nm}$ : Figure 3 shows the preparation of salmonella bacteria after exposure to lasers with a wavelength of $810 \mathrm{~nm}$ and a capacity of $70 \mathrm{~mW}$ and a 1.5 min stay time decreased from $9 \times 105$ colony $/ \mathrm{mL}$ formation unit in raw milk to $2.3310^{5} \mathrm{CFU}$.

Laser 1064 nm: When treated with 1064 nm laser milk within the IR sub-region for the same capacity and survival time of the sample, the results of the statistical analysis showed as shown in Fig. 3, a significant decrease in the number of Salmonella bacteria to (zero).

\section{Yeasts and modules}

Laser $650 \mathrm{~nm}$ : Figure 4 shows the preparation of yeast and mold for the sample of milk treated with a laser with a wavelength of $650 \mathrm{~nm}$ which is within the visual area and at a capacity of $70 \mathrm{~mW}$ and a survival time of $1.5 \mathrm{~min}$ as the number of yeast and mold to zero (zero) CFU mL $\mathrm{mL}^{-1}$. This is because the cell wall structure of the innate cell consists of multiple polysaccharides with high light permeability in the visible area and down to the nucleus. Since, the nucleus is responsible for all vital activities without which the cell diesthe nucleus in the fungus is clear and well-formed and in the fungus forming the nuclei, the nuclei are distributed in the cytoplasmum in a homogeneous manner. The light in the visible region is strongly absorbed by nuclear nuclei in DNA nuclei. Chemical reactions occur, DNA breaks, genetic structure changes and cell loss.

Laser $810 \mathrm{~nm}$ : Figure 4 shows the total number of yeasts and molds for milk samples treated with laser $810 \mathrm{~nm}$ wavelength and $70 \mathrm{~mW}$ and $1.5 \mathrm{~min}$ survival time significantly decreased to $2,667 \times 10^{5} \mathrm{CFU} \mathrm{mL}^{-1}$. Due to the effects of yeast and molded by photo energy incident on external structure of the cell wall of multiple polysaccharides at a high rate that allows light to pass in the area of the infrared medium which is absorbed 


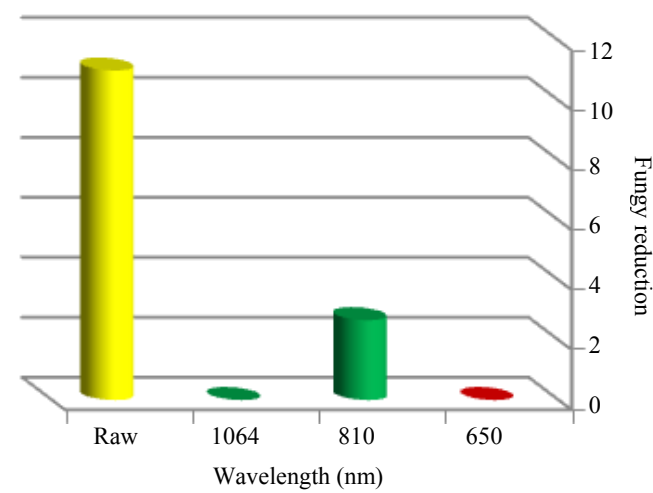

Fig. 4: The effect of different laser wavelengths on yeasts

strongly by the fluid cell of yeast and mold causes an increase in heat inside the cell causes the fragmentation of DNA and the deposition of cytoplasmic proteins.

Laser $1064 \mathbf{n m}$ : Figure 4 for the number of yeasts and molds for the milk sample treated with lasers with a wavelength of $1064 \mathrm{~nm}$ within the medium infrared region of $70 \mathrm{~mW}$ and $1.5 \mathrm{~min}$ survival showed a significant decrease in the total number of yeasts and molds to zero. Due to the high absorption of radiation by the liquid cell which caused the gradual increase of heat inside the cell and cause the breakdown of DNA in the cyto plasm and the disruption of the function of the plasma membrane and damage to cellular metabolism by inhibiting the enzymes leads to cell death.

\section{CONCLUSION}

The results of the study showed that the laser in the visible region superior to that of the nearby and intermediate infrared region because its low absorption coefficient in the milk and as a results produce high inactivation ratio. And also visible laser with a wavelength of $650 \mathrm{~nm}$ achieved a $100 \%$ reduction for all microorganisms at $1.5 \mathrm{~min}$ and $70 \mathrm{~mW}$. The laser with all wavelengths used as sterilized tool has been improve nutritional milk properties by forming new essential amino acids by interacting with other milk components.

\section{REFERENCES}

01. Malik, A.O.B., 2017. Effect of pasteurization by laser and heat on the cow's milk components. M.Sc. Thesis, Sudan University of Science and Technology, Khartoum, Sudan.

02. Al-Watban, F.A. and X.Y. Zhang, 2004. The comparison of effects between pulsed and $\mathrm{CW}$ lasers on wound healing. J. Clin. Laser Med. Surg., 22: $15-18$.

03. Bondia-Pons, C., A. Molto-Puigmart, I. Castellote and M.C. Lopez-Sabater, 2007. Determination of conjugated linoleic acid in human plasma by fast gas chromatography. J. Chromatogr., 1157: 422-429.

04. Hull, M.E., 1947. Studies on milk proteins. II. Colorimetric determination of the partial hydrolysis of the proteins in milk. J. Dairy Sci., 30: 881-884.

05. Krishnamurthy, K., A. Demirci and J.M. Irudayaraj, 2005. Staphylococcus aureus inactivation using pulsed UVlight for continuous milk treatment. Proceedings of the 2005 ASAE Annual Meeting, July 17-20, 2005, ASAE Tampa Convention Center, Tampa, Florida, pp: 1-11.

06. Hardee, M.W., L.J. Miserendino, W. Kos and H. Walia, 2002. Evaluation of the antibacterial effects of intracanal Nd: YAG laser irradiation. J. Endodont., 30: $377-380$. 